\title{
RENEWAL OF PLASMA THERAPY IN CLINICAL MEDICINE Century old concept of the first Nobel Prize winner Emil von Behring is its origin
}

\author{
TAPAS GOSWAMI ${ }^{1}$
}

${ }^{1}$ Former Principal Scientist, Immunology Section, Indian Veterinary Research Institute Izatnagar-243 122, Uttar Pradesh, India

Presently, we are facing a life-or-death grim situation due to corona virus pandemic.With no end to the coronavirus pandemic in sight as on end of May 2020. As of now, globally sixty seven lakh individuals have been disease-ridden with Covid-19 and about 4 lakh people have lost their lives as per report published from WHO website. National health system is in helpless situation, the WHO is also not confident in their advice. Across the globe, scientific fraternity is working with pandemic speed and unprecedented levels of collaboration to develop a vaccine for the disease are on. New drug development is not an easy task, all the low hanging fruits have already been picked up. Without waiting for unpredictable outcome of vaccine development, biologists are looking for plasma therapy as an alternative approach to treat the critical patients. Immediate availability of convalescent plasma is the real advantage over drug development. In the present manuscript, all efforts has been made to emphasize and elaborate the seminal work of German scientist Emil von Behring who conceptualised and finally demonstrated with authenticity that passive transfer of convalescent sera to naïve (susceptible, however not infected) animals can protect them from infectious disease for which he received $1^{\text {st }}$ Noble Prize in Physiology or Medicine in 1901.The subject of intravenous immunoglobulin therapy is a different aspect which is excluded intentionally in the present discussion.
It is needless to elaborate fundamental science behind plasma therapy to the knowledgeable readers, yet briefly I re-capitulate that, the plasma isolated from people who have recovered from the disease carry antibody generated by the immune system of the individual (donor) which when transfused to the freshly infected one (recipient) the transferred antibody can neutralise the pathogen or toxin as the case may be. The success depends upon concentrations of specific antibodies in the donor's plasma. Since 2014 clinical experience to treat the Ebola virus patients with convalescent plasma as an empirical approach with higher recovery rate has improved the confidence of physicians (van Griensven et al., 2016). Transfusion of convalescent plasma for viral infection like SARS-COV, H5N1 avian influenza and H1N1 influenza was also effective (Zhou et al., 2007; Chen et al., 2020). Adhering to strict recommended guidelines, the convalescent plasma is collected from individuals with complete resolution of symptoms, a gap of at least 14 days period to be before blood collection. For all practical purpose blood collected aseptically and plasma separated by apheresis are filtered before use. Individuals with evidence of Covid-19 positive detected through qRT-PCR or tested for antibody ELISA titer higher than $1: 1000$ or virus neutralizing antibody titer greater than 40 are selected for plasma donor. Virus neutralization test has to be performed using suitable cell lines such as 
Vero cells in 24 well plate employing diluted serum (two-fold serum dilution) constant virus protocol. Transfusion with one unit of $\mathrm{ABO}$ convalescent plasma is recommended, yet it varies due to variation in antibody titre in the donor plasma. To be most effective plasma, it should be tested for extraneous viral agent as per approved guidelines and to be used within days of collection avoiding storage (FDA, 2020). Individuals contracting the infection invariably generate detectable level of antibodies within a period of two weeks time. Accordingly, infusion of convalescent plasma at initial stage of infection can clear the virus more effectively. Plasma therapy at early stage of infection when the virus load is nominal, chances of recovery is high. The early administration of plasma can close the window of opportunity for severe infection (Cheng et al., 2005). Convalescent plasma therapy was shown to be safe and clinical outcomes improved, including fever, sequential organ failure assessment score, respiratory symptoms with reduced viraemia. Severity and progression of viral diseases positively correlate with viral loads in circulation. Similarly, amount of virus specific neutralizing antibody synthesized by the patient against the virus or passively received through plasma play vital role to neutralize the virus and its clearance from the system (Wang et al., 2020). Once all the precautionary safety measures are taken from blood collection to transfusion clinical practitioners are of opinion that there is negligible possibility or near to zero risk of infectious disease transmission through plasma. Apparently, plasma therapy can be used as a treatment module without any unpleasant effects. Passive administration of convalescent plasma may invite two types of risks; one is known risk and the other theoretical risk. Risk associated with inadvertent infectious agent and serum protein related allergic reactions are considered to be known risk, which are rare due to modern blood collecting and screenings techniques adapted in blood banks. The theoretical risk involves the phenomenon of antibody dependent enhancement of infection (ADE), for which several mechanisms have been propounded (Wan et al., 2020). Nevertheless, associated adverse reactions such as mild fever to life threatening anaphylactic reactions are some of the negative consequence occasionally observed with few individuals hypersensitive to serum protein that needs special attention (Leider et al., 2010). Academic and research groups are continuously monitoring the beneficial and adversative effect of passive antibody therapies for COVID-19 infection (Casadevall and Pirofski, 2020). Hopefully, convalescent plasma therapy may reduce the severity of the illness and hasten the recovery of COVID-19 patients. The convalescent plasma may not be an absolute solution for treatment rather it is just buying time till a vaccine or effective drugs percolate in clinics. We should remember that convalescent serum may act as stopgap measure in the current epidemic. To improve the percentage of survival among critical patients', expert groups have advocated using of convalescent plasma as a last option.

Our present interest is not to review the plasma therapy intended for COVID-19, instead to rewind the earlier scientific episode that highlighted the creative experimentation performed more than 120 years ago by two eminent researchers who conceptualised the fundamental behind the plasma therapy. German scientists Emil

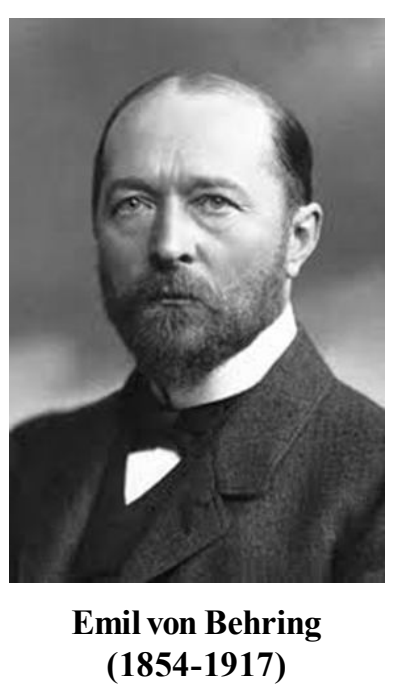

von Behring and Shibasaburo Kitasato postulated that the cell free substance developed in the blood of animals recovered from diphtheria and tetanus are able to neutralize the toxic effect produced by the respective pathogen. This ground breaking findings jointly published in German Medical Journal on $4^{\text {th }}$ December 1890 with the title "On the realization of immunity in diphtheria and tetanus in animals" (Behring and Kitasato, 1890). In present era with the advancement of scientific knowledge, critics may undermine their finding 
but during 1890, the concept of antibody was beyond imagination and never been speculated. In early 1900 s intellectual conflict was prevailing among researchers and there was debate over cells versus soluble mediators of immunity. It is only during 1930 the experiment performed by Elvin Kabat group, stated that a fraction of serum protein called gamma globulin (later named as immunoglobulin) can bind specifically with the toxin antigen and neutralise the ill effect of toxin (Tiselius and Kabat, 1939). In the initial experiment of Behring, several mice were immunized with inactivated Clostridium tetani, later blood serum collected from those mice was injected into abdominal cavity of six naïve mice. After a lapse of 24-hour, serum treated mice and control mice were injected with pathogenic tetanus bacteria. Interestingly all the control mice succumbed to infection within 48 hours of post challenge, whereas mice those received immune sera prior to challenge were unaffected remained healthy. The significance of the above experiment published by Behring and Kitasato demonstrated that sera collected from mice immunised with inactivated Clostridium tetani conferred protection to naïve mice against live tetanus bacilli as well as from lethal tetanus toxin. In that publication adequate information about diphtheria was not reported. Subsequently, adapting same experimental design, guinea pigs were immunized with Corynebacterium diphtheriae. Behring confirmed their earlier findings of protective role of post immunization serum which he published as solitary author. The exact conclusion mentioned in his own paper can be read like this "The possibility of cures for even highly acute diseases can thus no longer be ignored (Behring, 1890).Their joint experiments has given birth of two serious issues in biological science, the first one is on immunization, certain cell free substances appear in blood serum that can protect animals against pathogen, the second most critical issue was the substance which has protective role in serum is transferable from one individual to another and it can protect the recipient from pathogenic insult. If we will critically analyse their experiment it has emphasized that on immunization, animals develop active immunity and when serum is transferred to next individual the recipient accepts it as gift in the form passive immunity. During early 1900s worldwide child death was prevailing due to diphtheria, for which serum therapy was initiated with risk. The same approach later provided hope and sometimes relief for pneumonia and polio patients. In January 1892 first human trial of serum therapy against diphtheria was introduced by Emil Behring without much success due to limited serum in hand. Subsequently for large scale production antiserum was raised in horse. It is only during 1894 treatment with anti-serum was initiated incorporating 220 children suffering from diphtheria. About $77 \%$ recovery was recorded, that was the beginning of success journey for diphtheria treatment. With passage of time refinement and standardization of anti-toxin production reduced the diphtheria related mortality below $5 \%$ level. Till that time antibiotic was not discovered to take care of infection (Behring, 1893). The importance of anti-tetanus serum received its status during World War-I (1914) when large number of wounded soldiers contracted infection due to Clostridium tetani thereby, the demand of anti-tetanus serum was escalated (Kaufmann, 2017). Of course, there is less demand now due to public awareness and mass immunization programme with tetanus toxoid as proactive preventive measures taken to face the crisis in advance. The contribution of Emil Behring is immensely felt when we find antivenoms are available across the world to save human life from accidental snakebite. Despite the advancements in biotechnology hitherto we have to rely on passive serum therapy in the form of antivenom, as no other door is opened to neutralise the snake venom. The history of anti-venom begins with the work of the French physician Albert Calmette in the late Nineteenth 
century (Hawgood, 1999). Snakebite envenoming (SBE) affects as many as 2.7 million people every year, most of whom live in some of the world's most remote, poorly developed, tropical communities (Gutierrez et al., 2017). Considering the huge number of snakebite cases and associated demand of antisnake venom in the year 2017, WHO has recognised snakebite envenoming as an official addition to the list of Category A Neglected Tropical Diseases (WHO, 2018).

To achieve the highest level of success in serum/plasma therapy that has saved millions of precious human lives across the globe against pathogen a to $\mathrm{z}$ (anthrax to zika), innumerable animals have sacrificed their lives in the research labs. Clearly man had always benefited with the cost of animal's life. We can't ignore it. In the context of diphtheria, we have to recognise and pay our tribute for the heroic effort made by a sled dog BALTO delivered life-saving serum crossing 674 miles from Anchorage to Nome, a remote town of Alaska to save the children form diphtheria outbreak. That was the chilly windy weather of January 1925 with temperature below zero $-30^{\circ}$ Celsius; a horrific outbreak of diphtheria suddenly erupted among young children of the mining town Nome of Alaska. Unfortunately, available antiserum at Nome had passed its expiration date, only possibility was to logistic transport of fresh antiserum from another town Anchorage, almost 700 miles far of place (Henry, 2016). Roads were already closed due to thick blanket of ice, it was also not possible

\section{REFERENCES}

Behring E, 1890. Untersuchungenueber das Zustandekommen der Diphtherie-Immunitätbei Thieren. Dtsch Med Wochenschrift, 50: 11451148

Behring E and Kitasato S, 1890. Untersuchungen uber das Zustandekommen der DiphtherieImmunitat and der Tetanus-Immunitatbei Thieren. Dtsch Med Wochenschr, 16: 11451148, doi: $10.1055 / \mathrm{s}-0029-1207609$

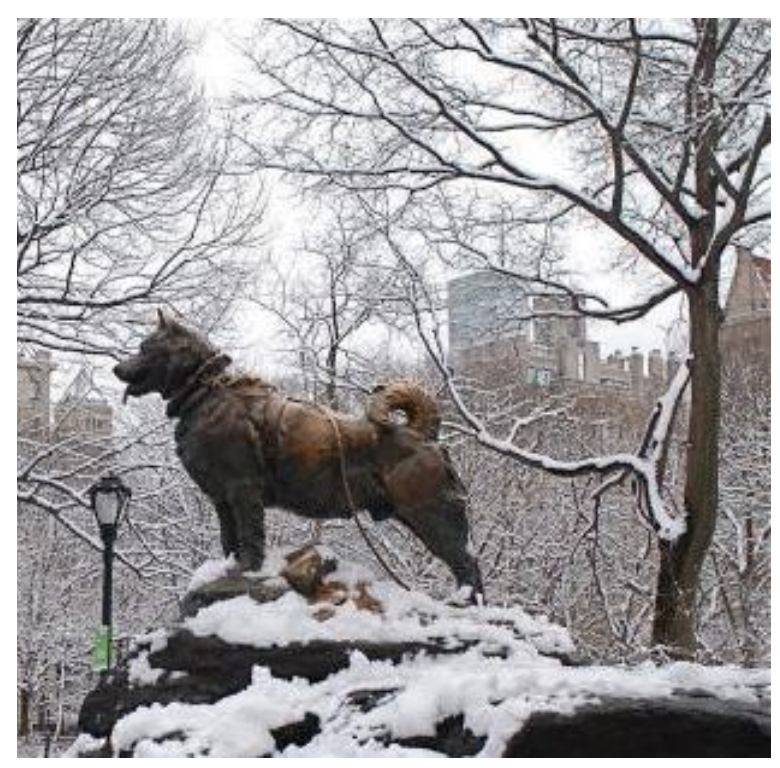

B A L T O (Sled- dog )

to use air or sea transport, as a winter storm prevented the use of the routes. Public health department decided to transport the antiserum through sled dogs with driver. On January 27, a relay of 20 dog teams and sled-dog racer Leonhard Seppala ventured out to haul serum from Anchorage. In the final leg of journey only two dogs survived and arrived in time to save many of the children. Balto, one of the heroic lead dogs who completed the final leg of treacherous journey is immortalized by a statue in New York City's Central Park. The story of Balto is real events in US history. After Balto died in 1933, his body was preserved and displayed at Cleveland's Natural History Museum. In 1995, a popular animated movie about Balto was released, adding to his fame (Salisbury and Salisbury, 2003).

Behring E,1893. Die Geschichte der Diphtherie; mitbesonderer Berücksichtigung der Immunitätslehre. Leipzig: G. Thieme 1893. Available online at: https:// www.biodiversitylibrary.org/bibliography/ 29160

Casadevall A and Pirofski LA, 2020. The convalescent sera option for containing COVID-19. J Clin Invest, 138003, doi:10.1172/JCI138003 
Chen L, Xiong J, Bao L and Shi Y, 2020. Convalescent plasma as a potential therapy for COVID-19. Lancet Infect Dis, 20(4): 398-400, doi:10.1016/ S1473-3099(20)30141-9

Cheng Y, Wong R, Soo YOY, Wong WS, Lee CK et al., 2005. Use of convalescent plasma therapy in SARS patients in Hong Kong. Eur J Clin Microbiol Infect Dis, 24(1): 44-46

Food and Drug Administration, 2020. Investigational COVID-19 Convalescent Plasma Guidance for Industry. U.S. Department of Health and Human Services F.D.A. Center for Biologics Evaluation and Research April 2020, Updated May 1, 2020, https://www.govinfo.gov/content/pkg/FR2020-03-25/pdf/2020-06222.pdf

Gutierrez JM, Calvete JJ, Habib AG, Harrison RA, Williams DJ et al., 2017. Snakebite envenoming. Nat Rev Dis Primers, 3: 17063, Epub 2017/09/ 15, doi: 10.1038/nrdp.2017.63 PMID: 28905944

Hawgood BJ, 1999. Doctor Albert Calmette 1863-1933: founder of antivenomous serotherapy and of anti-tuberculous BCG vaccination. Toxicon, 37: 1241-1258, doi: 10.1016/S00410101(99)00086-0

Henry BA, 2016. The Sled Dogs that Stopped an Outbreak, https://www.the-scientist.com/ foundations/the-sled-dogs-that-stopped-anoutbreak-32260

Kaufmann SHE, 2017. Remembering Emil von Behring: from Tetanus Treatment to Antibody Cooperation with Phagocytes. mBio, 8: e0011717, doi: 10.1128/mBio.00117-17

Leider JP, Brunker PA and Ness PM, 2010.
Convalescent transfusion for pandemic influenza: preparing blood banks for a new plasma product? Transfusion, 50(6): 1384-1398, doi:10.1111/j.1537-2995.2010. 02590.x

Salisbury G, and Salisbury L, 2003. The Cruelest Miles: The Heroic Story of Dogs and Men in a Race Against an Epidemic. W. W. Norton \& Company; USA

Tiselius A and Kabat EA,1939. An electrophoretic study of immune sera and purified antibody preparations. J Experi Med, 69: 119

van Griensven J, Edwards T, de Lamballerie X, Semple MG, Gallian P et al., 2016. Evaluation of convalescent plasma for Ebola virus disease in Guinea. N Engl J Med, 374(1): 33-42

Wan Y, Wan Y, Shang J, Sun S, Tai W et al., 2020. Molecular mechanism for antibody-dependent enhancement of coronavirus entry. J Virol, 94(5): e02015-19

Wang C, LiW, Drabek D, Okaba NMA, van Haperen $\mathrm{R}$ et al., 2020. A human monoclonal antibody blocking SARS-CoV-2 infection. bioRxiv, doi: $10.1101 / 2020.03 .11 .987958$

World Health Organization, 2018. Snakebite envenoming: Member States provide WHO with clear mandate for global action Geneva: World Health Organization; 2018. http:// www.who.int/neglected_diseases/news/ Snakebite-envenoming-mandate-globalaction/en/

Zhou B, Zhong N and Guan Y, 2007. Treatment with convalescent plasma for influenza A (H5N1) infection. N Engl J Med, 357(14): 1450-1451 